DOI 10.37882/2223-2982.2021.11.04

\title{
РЕЦЕПЦИЯ ВЗГЛЯДОВ КРАКОВСКОЙ ИСТОРИЧЕСКОЙ ШКОЛЫ В ПУБЛИЦИСТИКЕ ПЕТЕРБУРГСКОЙ ГАЗЕТЫ «КРАЙ
}

\section{RECEPTION OF THE VIEWS OF THE CRACOW HISTORICAL SCHOOL IN THE JOURNALISM OF THE ST. PETERSBURG "KRAJ" NEWSPAPER ${ }^{2}$ \\ M. Banaszkiewicz}

Summary: The article deals with the perception of the ideas of the socalled Cracow historical school by the "Kraj" newspaper. The latter represented opinions of Polish supporters of reconciliation with Russia after the suppression of the January uprising. A distinctive feature of the Cracow historical school was a pessimistic view of Poland's past. According to it the neighbors of Russia, Prussia and Austria are not to blame for the depriving the Polish-Lithuanian Commonwealth of independence in the XVIIIth century. Instead, it was the Polish elite, who failed to determine the correct path of development country. The article examines the views on the history of the founders of this trend in Polish historical thought: Walerian Kalinka (1826-1886) and Józef Szujski (1835-1883). Also, on the basis of the journalism of the «Kraj» newspaper in the 1880s it is shown how the legacy of the named historians was used by supporters of loyalism in relation to Russia headed by V.D. Spasovich.

Keywords: Russian Empire, Poland, Russo-Polish Relations, Cracow Historical School, Spasowicz, "Kraj" newspaper.
Банашкевич Миколай

К.и.н., н.С., Ягеллонский университет (Краков); приглашенный исследователь, Санкт-Петербургский государственный университет mikolaj.banaszkiewicz@gmail.com

Аннотация: Статья посвящена восприятию идей так называемой краковской исторической школы газетой «Край», являющейся печатным органом польских сторонников примирения с Россией после подавления январского восстания 1863-1864 гг. Отличительной чертой краковской исторической школы был пессимистический взгляд на прошлое Польши, сводящийся к мнению, что в потере независимости (XVIII в.) виноваты не соседствующие с Речью Посполитой державы (Россия, Пруссия, Австрия), а польские элиты, не сумевшие определить правильный путь развития страны. В статье рассматриваются взгляды на историю создателей данного направления польской исторической мысли: Валериана Калинки (1826-1886) и Юзефа Шуйского (1835-1883). В центре внимания находится их отношение к России. Также, на основании публицистики «Края» в 1880-е гг. показано, как наследие названных историков использовалось сторонниками лоялизма по отношению к России с В.Д. Спасовичем во главе.

Ключевые слова: Российская империя, Польша, российско-польские отношения, краковская историческая школа, Спасович, газета Край.
$\mathrm{H}$ и связи представителей т.н. краковской исторической школы с редакцией петербургской еженедельной газеты «Край», ни рецепция их взглядов на страницах этого периодического издания не были до сих пор предметом научного исследования. Наличие контактов польских исследователей с научным миром Петербурга при посредничестве выдающихся представителей столичной Полонии не подлежит сомнению. О них свидетельствует, в частности, хранящаяся в Ягеллонской библиотеке (Краков) переписка известного профессора уголовного права, адвоката и историка литературы В.Д. Спасовича (1829-1906). Остается, однако, вопрос: могло ли общее для обеих групп примиренческое отношение к государствам, лишившим Польшу независимости (соответственно: Австро-Венгерской и Российской империям), служить платформой согласия? Ведь краковская историческая школа по праву ассоциируется с консервативной группировкой т.н. станчиков, скорее питавших антироссийские чувства [18, с. 29-30]. Цель данной статьи - определить, как на страницах газеты «Край» представлялось и оценивалось наследие основоположников краковской исторической школы: ксендза Валериана Калинки (1826-1886) и Юзефа Шуйского (1835-1883).

Принято считать, что краеугольным камнем краковской исторической школы стали два фундаментальных труда второй половины 60-х гг. XIX в., посвященные закату Речи Посполитой. Это были четвертый том «Истории Польши» [31] Ю. Шуйского и «Последние годы правления Станислава Августа» [12] В. Калинки. В заключении

Исследование выполнено в рамках гранта № 19-18-00073 «Национальная идентичность в имперской политике памяти: история Великого княжества Литовского и Польско-Литовского государства в историографии и общественной мысли ХІХ-ХХ вВ.» Российского научного фонда.

2 This research was supported by the grant No 19-18-00073 «National Identity in the Imperial Politics of Memory: History of The Grand Duchy of Lithuania and the Polish-Lithuanian State in Historiography and Social Thought of the 19th - 20th Centuries» of the Russian Science Foundation. 
первого из них содержался вывод, что причиной упадка Речи Посполитой послужила «наша, длившаяся несколько веков, вина. Где-то в других местах историческая Немезис падает на королей и военачальников, у нас же всем весом тяготеет над народом». В свою очередь, введение ко второму из перечисленных трудов содержало мнение, что «поляки сами виновники [своего] упадка и что несчастия, павшие на нас, суть заслуженное народом покаяние» [19, с. 137]. Процитированные фрагменты стали своеобразным девизом краковской исторической школы.

Жизненный путь основателей этого направления не был одинаковым. Становление личности В. Калинки включало фазу политической деятельности и фазу научной деятельности, совмещаемой с духовной службой (в 1868 г. он вступил в орден воскресенцев). Будучи сначала демократом, антиклерикалом и участником антиавстрийского мятежа 1846 г., спустя две декады активного участия заграницей в польском движении за независимость он окончательно стал примиренцем и консерватором, борющимся с любым проявлением революции. В конце концов Калинка поселился во Львове. Несмотря на деятельное сотрудничество с Академией знаний, он так и не сумел получить место в университетских структурах [14, с. 449-452].

Совсем иначе протекала карьера Ю. Шуйского, умело использовавшего все выпадавшие ему шансы в самых разных сферах деятельности: научной, литературной и политической. С момента основания в Кракове Академии знаний (1872) вплоть до своей смерти он состоял ее генеральным секретарем. Защитив в Ягеллонском университете докторскую диссертацию, он возглавил (в то время единственную на всей территории бывшей Речи Посполитой) кафедру истории Польши, став со временем ректором университета. При этом львиную долю времени Шуйский уделял литературному творчеству. Не стоит забывать и о его деятельности на политической ниве: он был депутатом Краевого (т.е. галицийского - в данном случае, охватывавшего всю территорию австрийской части Польши) сейма, членом Палаты господ в австрийском Государственном совете и одним из передовых идеологов группировки станчиков [25].

Термин «краковская историческая школа» по сути был ярлыком, навязанным группе исследователей их антагонистами, представлявшими «варшавскую историческую школу», куда входили Тадеуш Корзон (18391918), Владислав Смоленский (1851-1926), Александэр Рембовский (1847-1906). Сами представители первого направления предпочитали определения школы как «критичной» или «новой», таким образом подчеркивая использование современных исследовательских приемов. В данном случае современность не подразумевала позитивистского подхода, ибо создатели школы во многом подверглись влиянию романтизма; именно об этих людях пойдет речь в дальнейшем [9, с. 301-302, 339-340]. Так или иначе, данный термин запечатлелся в польском историческом сознании. Его приметой стал пессимистический взгляд на историю Польши.

Охарактеризовать отношение обоих создателей краковской исторической школы к России не представляется возможным без биографических сюжетов. В юности оба они активно - хоть и в разной форме - участвовали в борьбе с Россией за независимость Польши. В. Калинка, будучи эмигрантом, сблизился с Отелем Ламбер - важнейшим политическим центром польской эмиграции, возглавляемым кн. Адамом Чарторыйским (1770-1861). С декабря 1855 г. В. Калинка содействовал формированию Польской дивизии султанских казаков, предназначенной для участия в Крымской войне. Впоследствии он добился создания «Польских ведомостей» - печатного органа, призывавшего к сопротивлению странам-захватчикам. Наконец, он принимал деятельное участие в разных комиссиях Бюро польских интересов. В 1862 г. по его инициативе была учреждена «российская комиссия», ставящая своей целью сотрудничество с А.И. Герценом и лондонским центром русской эмиграции. [23, с. 185-186, 204-206, 229, 231-233, 235, 242]. В свою очередь об отношении Ю. Шуйского к борьбе с Россией нагляднее всего свидетельствует поддержка, оказанная им январскому восстанию. Вступив в ряды конспираторов в первые месяцы 1863 г., он доставлял оружие повстанцам из Царства Польского. Позже Шуйский редактировал подпольный журнал «Вперед».

Январское восстание стало переломным событием в процессе духовного и политического становления личностей представителей краковской исторической школы. Поражение в борьбе с Россией сделало В. Калинку и Ю. Шуйского противниками насильственных выступлений против властей разделивших Польшу государств. Консервативные историки оказались в ряду критиков повстанческой традиции и вообще всяких заговоров, что отразилось и на их отношении к более ранним восстаниям (не только против России) [22, с. 63-66]. Независимо от превратностей судьбы, которая столкнула корифеев краковской исторической школы с Российской империей, стоит проследить наличие российского вопроса в их научном творчестве. Сразу необходимо отметить, что ни В. Калинка, ни Ю. Шуйский не занимались специально историей России. Следовательно, делать выводы об их отношении данному вопросу можно лишь основываясь на их исследованиях по польской истории.

В отношении В. Калинки к России присутствовали два измерения: религиозно-культурное и политическое. Первое подчеркивало ее чуждость для поляков, проистекающую из принадлежности к другому цивилизационному кругу. По мнению ученого, Россия - часть Азии. 
Здесь дала о себе знать убежденность, что границы Европы ограничены протяженностью латинской культуры. Точка зрения В. Калинки отчасти была следствием того, что, как католический священник, поддерживавший униатов, он оценивал Российскую империю сквозь призму ее конфессиональной политики в западных губерниях. Эта оценка должна была оказаться негативной. Здесь мы имеем дело с отождествлением польскости с католицизмом [8, с. 19-20].

Политическое измерение мировоззрения В. Калинки наиболее полное отражение нашло в работе «Царство польское и тайные общества» (1895). В ней историк осуждал польское конспиративное движение в российской части разделенной Польши. Он с уважением отзывался об Александре I, видя в нем царя, который уважал автономию конституционного Царства Польского. Совсем иначе он оценивал царствование Николая I, отличавшееся, по его мнению, ненавистью к полякам и, якобы, свидетельствующее об азиатском характере России. В то же время В. Калинка утверждал, что повод к репрессиям дали сами поляки, восстав в 1830 г. против законной власти. На его взгляд, поражение Ноябрьского восстания и было приговором Провидения. Историк трактовал восстание как проявление болезненной польской склонности составлять заговоры. Еще более резко он относился к Январскому восстанию, увидев в нем Божье проклятие. Последовавшие вслед за подавлением мятежа репрессии он воспринимал как наказание поляков за грехи предыдущих поколений [21, с. 149-157, 161-165, 158-169, 171-174].

В свою очередь, взгляд Ю. Шуйского на Россию и ее значение в польской истории менялся. Вплоть до 70-х гг. XIX в. краковский историк смотрел на Россию примерно так же, как В. Калинка. По его мнению, она была составной частью Востока, т. е. принадлежала к миру, находившемуся в культурном конфликте с цивилизованным, основанным на католицизме Западом. Шуйский считал, что Польша возглавляет славянство, защищая его сразу от двух ориентальных деспотизмов: российского государства и русского общества, компенсирующего собственное рабство порабощением других народов. [8, с. 21-22]. Существенным различием было то, что краковский историк считал Русь обособленной от Москвы общностью, а русинов противопоставлял москалям [15, с. 473-475].

Более сдержанная позиция Ю. Шуйского по этим вопросам нашла своё полное отражение в обобщающей работе «Польская история, сжато рассказанная в двенадцати книгах» [33]. В ней краковский историк предложил новую постановку проблемы, отказавшись от основных идей пропитанного романтическим национализмом четырехтомника «История Польши» (1862-1866). В новом труде он не стигматизировал Россию, а принадлежность Польши к западному миру объяснял не только выбором латинской ветви христианства, но и спецификой её политических институтов вплоть до XIV столетия, когда в Польше преждевременно начался развивать парламентаризм, ослаблявший монархическое начало и само государство [36, с. 230-235].

В рассуждениях Ю. Шуйского об исторических судьбах Польши ключевой была оценка унии с Литвой, отличавшаяся противоречивостью. В политическом плане она была отрицательной, что предопределялось упадком Речи Посполитой в конце XVIII в. Истоки неудачи проекта совместного государства лежали в его основах - утверждал Ю. Шуйский. Призвание на польский трон Владислава Ягелло привело к своеобразной ситуации: интересы наследного правителя Великого Княжества Литовского противоречили интересам Короны Королевства Польского. Ослабление доверия к королю, вынуждавшее последнего к уступкам в пользу духовенства и магнатов, было чревато постоянным подрывом престижа верховной власти. Деструктивное влияние экспансии на литовско-русские земли состояло в выборе ошибочного вектора развития. Вместо того, чтобы осуществлять западную модель, Польша сама начала внедрять ее на огромном пространстве. Усилия по освоению новых территорий отвлекли основные силы нации от сердцевины государства, а в дальнейшей перспективе вели к растворению польскости. Люблинская уния 1569 г., по мнению Шуйского, усугубила эти пагубные тенденции, чему способствовали, с одной стороны, польская колонизаторская политика, с другой - политическая незрелость инкорпорируемой литовско-русской элиты [26, с. $24-26,43-46]$.

Несмотря на негативную оценку сложившихся в период унии с Литвой форм народной жизни и государственной модели, Ю. Шуйский в целом позитивно относился к ее содержанию, т.е. к цивилизационным ценностям. Он считал, что реализованная Польшей цивилизаторская миссия на Востоке составляла ее историческое призвание. Привитие на территории между Западной Двиной и Днепром идеалов права и свободы - вот смысл этого призвания, и одновременно повод гордиться этим, невзирая на политическую цену. Вывод гласил: благодаря польским усилиям влияние Европы расширилось, хотя было равнозначно с роковой для Польши конфронтацией с восточными деспотиями: Московским государством и Турцией [20, с. 43-44, 48-49, 53; 7, с. 257-274]. Как сам этот вывод, так и приведенная выше аргументация вполне укладываются в рамки романтической историософии.

Полученное в апреле 1882 г. разрешение издавать в Петербурге еженедельную газету «Край» под номинальной редакцией Э. Пильца (1851-1929) свидетельствовало об изменении отношения властей к польскоязычной прессе. Очевидно, в доживавшем последние месяцы игнатьевском Министерстве внутренних дел вновь по- 
явились надежды использовать ее с целью поощрения верноподданнических чувств на территории бывшего Царства Польского. Данный факт был несомненным успехом политического лагеря, олицетворяемого В.Д. Спасовичем, поскольку именно он разработал программу газеты и содействовал ее учреждению. Хоть издание и подвергалось предварительной цензуре и не могло свободно высказываться об отношении поляков к России, со временем оно обрело репутацию «польского консульства в городе на Неве». При этом редакция не скрывала своего стремления оказывать влияние на общественное мнение Царства Польского и западных губерний [13, с. 55-57]. Другое дело, что в сознании польских современников «Край» именовался приводным ремнем распоряжений царских властей. Эта репутация упрочилась вследствие огласки польского перевода брошюры, в которой редакция газеты указывала на пользу, приносимую русскому делу [2].

Примиренческая программа, пропагандировавшаяся на страницах еженедельника, апеллировала к идеалам и понятиям эпохи великих реформ. Впервые сформулирована Э. Пильцом в «Голосе» [3], она предусматривала соглашение, основанное на уступках с обеих сторон: отказ поляков от стремлений к независимости в обмен на гарантии этнической и культурной автономии, свободное институциональное развитие, равноправие польского населения. Идейный облик «Края» в целом укладывался в более широкое течение социального либерализма [1; 30, с. 24-41]. Ключевое значение имеет отношение редакции петербургской газеты к консерватизму галицийских элит. Очевидно, подход к социальным и экономическим вопросам «Края» противоречил чувству сословной исключительности последних. Также, совсем не в традиционном консервативном ключе оценивались заслуги католицизма. Поэтому не мудрено, что «Край» оказывал поддержку либеральным политическим силам. Положение, однако, изменилось в 1890-ые гг. С тех пор в глазах сотрудников «Края» станчики являлись продолжателями деяний А. Велепольского, а реализованная ими примиренческая политика принесла Галиции ощутимую пользу. Важно и то, что в петербургском еженедельнике подчеркивалось критическое отношение краковских консерваторов к повстанческой традиции. Публицисты «Края» с уважением отзывались о «Портфеле Станчика» (35) - своего рода программном манифесте краковских охранителей. На столбцах газеты неоднократно выдвигались на первый план цитаты, почерпнутые из работ В. Калинки и Ю. Шуйского [16, с. 280-284].

Было бы невозможным вполне охарактеризовать отношение «Края» к польской истории без обращения к воззрениям интеллектуального предводителя газеты и петербургских примирителей [6]. Отношение В.Д.Спасовича к истории Польши отразилось в статье, полемизирующей с одним из монументальных сочинений истории историографии [27]. По мнению историка литературы, важнейшие заслуги представителей краковской исторической школы состояли в том, что они «доказали невозможность дальнейшего существования бывшего политического организма государства и необходимость упадка по природе вещей, а не по случайности». Кроме этого, автор выдвигал аргумент, сближающий его с мышлением старшего поколения краковских историков. В.Д. Спасович утверждал, что упадок государственности не означает конца существования польского народа и подчеркивал проявлявшуюся в культуре «непрерывность его нравственной жизни». Цивилизационное достояние, - резюмировал мыслитель, - и было лейтмотивом польской истории» [29, с. 285-286].

Перейдем к тому, как на страницах «Края» были представлены научные изыскания В. Калинки и Ю. Шуйского. Последний умер спустя полгода после основания газеты, поэтому неизвестно, как он относился к программе «партии петербургских реалистов» и готов ли был ее поддержать в своих публицистических выступлениях. Зато можно с полной уверенностью сказать, что линии В.Д. Спасовича и Э. Пильца содействовал В. Калинка, согласившийся опубликовать в 1885-1886 гг. фрагменты незавершенного труда «Четырехлетний сейм», в котором рассматривались усилия по модернизации общественно-политического строя Речи Посполитой в последние годы ее существования. Это вовсе не означает, что взгляды ученого ксендза и редакции «Края» полностью совпадали. В передовой статье, разъясняющей позицию В. Калинки в отношении еженедельнка, подчеркивалось одно из глубинных различий между ними: отношение к привилегированному положению Католической церкви в дораздельной Польше и к присущей В. Калинке тенденции отождествлять ее с преуспеянием отечества [5, с. 2].

Упрек в склонности к религиозному учению в ущерб исторической истине встречался и в других отзывах о корифее краковской исторической школы. Так, известный познанский историк К. Яроховский (1828-1888) назвал В. Калинку «мужем религиозно-политического направления», что - по его мнению - вредило ему как историку [10, с. 30-31]. Тенденцию смешивать историю с требованиями теологии, наблюдавшуюся в работах ксендза, отмечал также его идейный оппонент Т. Корзон. Критик признавал, что в своих ученых исследованиях В. Калинка нередко выступал больше в качестве духовного лица, чем ученого [17, с. 4].

В целом, однако, редакция «Края» считала В. Калинку великим историком, равным светочам европейской историографии. В поминальной передовой статье редакция объявляла его беспристрастным правдолюбцем, умевшем отдать должное всем участникам исторического процесса, вне зависимости от конфессиональной принадлежности. Изложение Калинкой фактов, утверж- 
дал автор статьи, лишь на первый взгляд казалось холодным. На самом же деле его неотразимая сила заключалась в логике приводимых фактов, что помогало «сразу выворачивать наиболее укорененные убеждения». [24, с. 1] Панегирик В. Калинке-историку не мешал, однако, «Краю» заявить несогласие с практической деятельностью умершего по русинскому вопросу [24, с. 2]. Само собой разумеется, что редакция даже не заикнулась об антироссийской деятельности В. Калинки, почти целиком заполнившей эмигрантский период его жизни.

Имя Ю. Шуйского встречалось на столбцах «Края» не так часто - однако редакция неизменно отдавала ему дань уважения. Наиболее выразительно это отразилось в поминальной передовой статье, посвященной заслугам только что ушедшего из жизни ученого. Редакция утверждала, что умерший - «один из нескольких главнейших застрельщиков морального возрождения, поднятия из развалин нашего общества после великой катастрофы 1863 года». К числу достижений Ю. Шуйского причислялось, помимо прочего, «избавление от всевозможных [политических] призраков», «нравственное отрезвление», «обнажение грехов». Все это стало возможным благодаря преодолению наследия романтического историописания - утверждала газета [3, с. 1].

Знаменательно, что, характеризуя кредо Ю.Шуйского, «Край» указывал на его запомнившееся публицистическое выступление «Фальшивая история как наставница фальшивой политики». Петербургская газета опубликовала целиком эту статью. В ней, помимо освещения методологических приемов школы, краковский историк отверг тезис о том, что история Польши есть воплощение идеи свободы. «Возрождение польского народа, твердил Ю. Шуйский - требует не следования традициям Речи Посполитой, оказавшимся несостоятельными, но наоборот - осознания причин политического упадка» [32]. Обращение к объективной исторической правде, как единственному средству, дающему народу возможность продолжать свой исторический путь - вот наследие Ю. Шуйского, с которым в дальнейшем идентифицировались его преемники на поприще науки [28, с. 2].
В 1889 г. «Край» перепечатал лекцию, прочитанную краковским историком по случаю открытия новой кафедры в Ягеллонском университете. В ней Ю. Шуйский сформулировал кредо краковской исторической школы, обосновав тезис о пользе, вытекающей из критического осмысления прошлого. Текст был снабжен припиской редакции, что автор - «великий писатель, наметивший новые пути нашей историософии и приложивший крепкую руку к политической образованности общества» [34, с. 1]. Историк предупреждал перед использованием истории в качестве репозитория громких фраз, чрезмерно возбуждающих польский национальный дух. «Истории и историографии в нашем польском обществе, заявлял Ю. Шуйский, - угрожает огромная опасность, вытекающая из нашего внутреннего положения». По его мнению, представления поляков о себе как страдающей стороне побуждают их искать для себя каких-то особых историософских прав и вырабатывают у них привычку не считаться с политической реальностью [34, с. 2]. Итак, тезисы перепечатанной «Краем» лекции Ю. Шуйского обосновывали необходимость расстаться с иллюзиями, питаемыми сторонниками радикального решения польского вопроса.

Из приведенного материала видно, что рецепция взглядов на польское прошлое старших представителей краковской исторической школы в публицистике «Края» 1880-х гг. занимала не последнее место. Идейные различия на фоне либерально-консервативных споров не играли здесь решающей роли. В интеллектуальном плане краковских консерваторов и петербургских либералов-поляков объединяло стремление преодолеть романтическое наследие польской общественной мысли и сопутствовавшей ей политизированной историографии. В политическом же смысле общим было стремление найти (в случае станчиков - упрочить) компромисс между поляками и властями государств, разделивших Речь Посполитую в конце XVIII в. Точкой отсчета для публицистов «Края» и краковских историков было Январское восстание 1863 г., ставшее, по их мнению, результатом непростительной, чреватой неисправимыми последствиями политической ошибки.

\section{ЛИТЕРАТУРА}

1. Банашкевич М. Край. www.polskipetersburg.ru [доступ: 08.09.2021]

2. Очерк публицистической деятельности польской газеты «Кгај» за десять лет (1882-1892). СПб.: [б. и.], 1892.

3. [Пильц Э.] Обрусение или объединение // Голос. 1881. № 56-58 (25-27 февраля).

4. [Artykuł wstępny] // Kraj. 1883. Nr 5. S. 1.

5. [Artykuł wstępny] // Kraj. 1884. Nr 6.S. 1-2.

6. Banaszkiewicz M., Spasowicz W. http://www.polskipetersburg.pl/hasla/spasowicz-wlodzimierz (доступ: 22 сентября 2021)

7. Błachowska K. Wiele historii jednego państwa. Obraz dziejów Wielkiego Księstwa Litewskiego do 1569 roku w ujęciu historyków polskich, rosyjskich, ukraińskich, litewskich i białoruskich w XIX wieku. Warszawa: Fundacja Naukowa Otwarte Historie, Wydawnictwo Neriton, 2018. 412 c.

8. Filipowicz M. Wobec Rosji. Studia z dziejów historiografii polskiej od końca XIX wieku po II wojnę światową. Lublin: IEŚ-W, 2000. 222 S. 
9. Grabski A.F. Metodologiczne problemy tzw. krakowskiej szkoły historycznej // Grabski A.F. Orientacje polskiej myśli historycznej. Studia i rozważania. Warszawa: Państwowe Wydawnictwo Naukowe, 1972. S. 301-340.

10. Jar[ochowski] K. Kalinka o Dez. Chałapowskim // Kraj. 1885. Nr 49. S. 30-31.

11. Kalinka W. Królestwo Kongresowe i związki tajne // Przegląd Polski. 1895. Z. 4. S. 1-44; Z. 5. S. 295-337; Z. 6. S. 557-587.

12. Kalinka W. Ostatnie lata panowania Stanisława Augusta. Dokumenta do historii drugiego i trzeciego podziału. Cz. 1. Poznań: Nakładem Księgarni Jana Konstantego Zupańskiego, 1868. 299S.

13. Kidzińska A. «Obrona bytu». Wczesne poglądy polityczne ugodowców z Królestwa Polskiego w świetle petersburskiego «Kraju» (1882-1896) // Annales Universitatis Mariae Curiae-Skłodowska. Sectio F. 2001. T. 56. S. 55-82.

14. Kieniewicz S. Kalinka Walerian // Polski Słownik Biograficzny. Wrocław-Warszawa-Kraków: Zakład Narodowy im. Ossolińskich - Wydawnictwo Polskiej Akademii Nauk. 1964-1965. T. XI. S. 449-452.

15. Klassa B. Józef Szujski wobec Rusi i Rosji // Historia - mentalność - tożsamość. Rosja i Europa Zachodnia w polskiej i ukraińskiej historiografii XIX i XX wieku. Red. Koko E., Nowak M., Zaszkilniak L. Gdańsk-Sopot: Wydawnictwo Uniwersytetu Gdańskiego, 2013. S. 464-476.

16. Kmiecik Z. «Kraj» za czasów redaktorstwa Erazma Piltza. Warszawa: Państwowe Wydawnictwo Naukowe, 1969. $501 \mathrm{~S}$.

17. Korzon T. Waleryan Kalinka jako historyk // Przegląd Literacki. Dodatek do «Kraju». 1887. Nr 2. S. 3-4.

18. Król M. Przedmowa // Stańczycy. Antologia myśli społecznej i politycznej konserwatystów krakowskich. Warszawa: Instytut Wydawniczy PAX, 1985. S. 5-37.

19. Maternicki J. Historia i życie narodu. Poglądy i postawy historyków polskich XIX i XX w. Rzeszów: Wydawnictwo Uniwersytetu Rzeszowskiego, 2009. $490 \mathrm{~S}$.

20. Maternicki J. Józef Szujski wobec tzw. idei jagiellońskiej // Historia XIX i XX wieku. Studia i szkice. Prace ofiarowane Henrykowi Jabłońskiemu w siedemdziesiątą rocznicę urodzin. Wrocław: Zakład Narodowy im Ossolińskich, 1979. S. 41-55.

21. Maternicki J. Walerian Kalinka (1826-1886) i jego badania nad epoką porozbiorową. Rzeszów: Wydawnictwo Uniwersytetu Rzeszowskiego, 2013.254 S.

22. Michalska-Bracha L. Krakowska szkoła historyczna wobec powstania styczniowego // Krakowska szkoła historyczna a Polskie Towarzystwo Historyczne. Studia historiograficzne. Red. Biliński P., Plichta P. Warszawa-Kraków: Polskie Towarzystwo Historyczne, Instytut Studiów Międzykulturowych Uniwersytetu Jagiellońskiego w Krakowie, 2017. S. 61-73.

23. Mrówczyński J.Ks. Walerian Kalinka. Życie i działalność. Poznań: Księgarnia św. Wojciecha, 1973. 694 S.

24. Na grobie ś. p. Waleryana Kalinki // Kraj. 1886. Nr 50. S. 1-2.

25. Red. Szujski Józef Jerzy Karol // Polski Słownik Biograficzny. Warszawa-Kraków: Wydawnictwo Towarzystwa Naukowego Societas Vistulana, 2013-2014. T. XLIX. S. 176-187.

26. Słoczyński H.M. Główne idee syntezy dziejów Polski Józefa Szujskiego // W służbie nauki. 2015. Nr 26. S. 17-49.

27. Smoleński W. Szkoły historyczne w Polsce. (Główne kierunki poglądów na przeszłość). Warszawa: Drukarnia Artystyczna Saturnina Sikorskiego, 1898. 160 S.

28. Smolka S. Słowo wstępne do historii polskiej. (Wykład wstępny prof. Stan. Smolki przy objęciu katedry w uniwersytecie jagiellońskim // Kraj. 1884. Nr 31. S. 2-6.

29. Spasowicz W. Zadania historii // Spasowicz W. Liberalizm i narodowość. Wybór pism. Kraków: Ośrodek Myśli Politycznej, 2010. S. 277-288.

30. Szczepaniak A. Od autonomii do niepodległości. Działalność polityczna Erazma Piltza w latach 1914-1929. Opole: Wydawnictwo Uniwersytetu Opolskiego, 2015. $593 \mathrm{~S}$.

31. Szujski J. Dzieje Polski podług ostatnich badań. T. 4. Lwów: Nakładem Karola Wilda, 1866. 752 S.

32. Szujski J. Fałszywa historia jako mistrzyni fałszywej polityki // Kraj. 1883. Nr 19. S. 2-8; Nr 20. S. 2-8.

33. Szujski J. Historyi polskiej treściwie opowiedzianej ksiąg dwanaście. Warszawa:W drukarni J. Bergera, 1880. 439 S.

34. [Szujski J.]. Wstępna prelekcya do kursu historii polskiej w Uniwersytecie Jagiellońskim // Przegląd Literacki. Dodatek do «Kraju». 1889. Nr 52. S. 1-4.

35. Teka Stańczyka. Kraków: Drukarnia Uniwersytetu Jagiellońskiego, 1870. 156 S.

36. Wierzbicki A. Wschód-Zachód w koncepcjach dziejów Polski. Z dziejów polskiej myśli historycznej w dobie porozbiorowej. Warszawa: Państwowy Instytut Wydawniczy, 1984.346S.

(c) Банашкевич Миколай (mikolaj.banaszkiewicz@gmail.com).

Журнал «Современная наука: актуальные проблемы теории и практики» 